\title{
Effects of hyperglycemia on sperm and testicular cells of Goto-Kakizaki and streptozotocin-treated rat models for diabetes
}

\author{
Sandra Amaral ${ }^{\mathrm{a}}$, António J. Moreno ${ }^{\mathrm{a}}$, Maria Sancha Santos ${ }^{\mathrm{a}}$, \\ Raquel Seiça ${ }^{\mathrm{b}}$, João Ramalho-Santos ${ }^{\mathrm{a}, *}$ \\ ${ }^{a}$ Department of Zoology, Center for Neuroscience and Cell Biology, University of Coimbra, 3004-517 Coimbra, Portugal \\ ${ }^{\mathrm{b}}$ Faculty of Medicine and Center for Neuroscience and Cell Biology, University of Coimbra, Coimbra, Portugal
}

Received 20 April 2006; received in revised form 16 June 2006; accepted 18 June 2006

\begin{abstract}
Diabetes mellitus is a degenerative disease that has deleterious effects on male reproductive function, possibly through an increase in oxidative stress. This study was conducted in order to clarify the mechanisms by which oxidative stress influences animal models for both type 1 (streptozotocin-treated rats, STZ) and type 2 (Goto-Kakizaki (GK) rats) diabetes. We determined the extent of lipid peroxidation, protein oxidation, lactate levels, adenine nucleotides, adenylate energy charge and the activity of glutathione peroxidase, glutathione reductase and lactate dehydrogenase, in isolated testicular cells of control and diabetic rats. We have also correlated these parameters with sperm count and motility. Sperm concentration and motility were decreased in STZtreated rats. ATP levels were lower in rats treated with STZ for 3 months, in contrast to GK and rats treated with STZ for 1 month, suggesting an adaptative response. STZ-treated rats showed increased lipid peroxidation after 1 week and 3 months of treatment. Glutathione reductase (G-red) activity was found to be higher in GK rats. Glutathione peroxidase activity was lower in GK and rats treated with STZ for 1 month, which is in accordance with the proposal of functional recovery in these animals. We conclude that hyperglycemia has an adverse effect in sperm concentration and motility via changes in energy production and free radical management. Furthermore, both animal models, particularly GK rats and rats treated with STZ for 1 month, present some metabolic adaptations, increasing the efficiency of mitochondrial ATP production, in order to circumvent the deleterious effects promoted by the disease.
\end{abstract}

(C) 2006 Elsevier Inc. All rights reserved.

Keywords: Diabetes mellitus; Sperm; Oxidative stress; Antioxidant enzymes; Reproductive function

\section{Introduction}

About $90 \%$ of diabetic patients have disturbances in sexual function, including a decrease in libido, impotence and infertility, in the latter case due to testicular

\footnotetext{
* Corresponding author. Tel.: +351 239855760; fax: +351239855789 .

E-mail address: jramalho@uc.pt (J. Ramalho-Santos).
}

dysfunction associated with sustained hyperglycemia $[1,2]$. Diabetes mellitus (DM) is a heterogeneous metabolic disorder characterized by hyperglycemia resulting from defective insulin secretion, resistance to insulin action or both [3]. Type 1 diabetes is the consequence of an autoimmune-mediated destruction of pancreatic $\beta$-cells, leading to insulin deficiency, while type 2 diabetes is characterized by insulin resistance and relative, rather than absolute, insulin deficiency [4]. Growing evidence indicates that oxidative stress is 
increased in diabetes, due to the overproduction of reactive oxygen species (ROS), and decreased efficiency of antioxidant defences [5,6]. Oxidation of lipids, proteins and other macromolecules (such as DNA) occurs during the development of diabetes [7]. Mitochondrial DNA mutations have also been reported in diabetic tissues, suggesting oxidative stress-related mitochondrial damage [8].

Hyperglycemia leads to the increased production of free radical intermediates via at least four different routes: increased glycolysis; intercellular activation of the sorbitol (polyol) pathway; auto-oxidation of glucose and non-enzymatic protein glycation $[9,10]$. To control the flux of ROS, aerobic cells have developed an antioxidant defense system, which includes enzymatic and non-enzymatic components [11]. The antioxidant system consists of low molecular weight antioxidant molecules and various antioxidant enzymes [12-15]. Glutathione (GSH), the most prevalent low-molecular weight antioxidant peptide, and GSH-related antioxidant enzymes, such as glutathione peroxidase (G-Px), glutathione reductase (G-Red) and glutathione $S$ transferase (GST), are the most important enzymes of this cellular antioxidant system. G-Px catalyses the reduction of hydrogen peroxide and organic hydroperoxides by transferring electrons from GSH, thus forming GSSG. In turn, GSSG is then reduced back to GSH by G-Red [16]. The stability and capacity of antioxidant status during chronic diabetes seriously influences the outcome of the long-term complications caused by oxidative stress [17].

Mammalian sperm cells present a specific lipidic composition, with a high content of polyunsaturated fatty acids, plasmalogens and sphingomyelins. The lipids in spermatozoa are the main substrates for peroxidation, and Aitken et al. [18] showed that excess amounts of ROS and free radicals have adverse effects on sperm motility and fertility. Furthermore, oxidative damage to lipids and DNA of spermatozoa is associated with declining motility and diminished fertility of human sperm [1921]. However, the mechanisms of altered spermatogenesis in diabetic men are poorly understood. In this regard, animal models for diabetes are important research tools, since they provide insights which are almost impossible to duplicate in human populations [22,23]. In the present study, we used STZ-induced diabetic rats as models for type 1 diabetes and Goto-Kakizaki (GK) rats as models for type 2 diabetes. STZ-induced diabetic rats are obtained after selective destruction of $\beta$ cells by streptozotocin (STZ), an antibiotic with diabetogenic effects. STZ-injected rats present many characteristics seen in insulin-dependent diabetic human patients, such as hypoinsulinemia, hyperglycemia, ketonuria, and hyperlipidaemia [23]. On the other hand, Goto-Kakizaki (GK) rats are currently used as an animal model for type 2 diabetes. This animal is a non-obese, spontaneously diabetic rat [22], produced by selective breeding of Wistar rats, using glucose intolerance as a selection index [24-27]. GK rats exhibit a moderate but stable fasting hyperglycemia, which does not progress to a ketotic state. Furthermore, the GK rat is one of the best characterized animal models of spontaneous non-obese type 2 diabetes mellitus, since it exhibits similar metabolic, hormonal, and vascular disorders as the human disease [22]. Furthermore, in the initial stages of diabetes, GK rats do not exhibit severe complications associated with the disease, constituting an important model to study the initial events of diabetes [28].

In the present work, we have tried to elucidate the mechanisms by which diabetes and associated oxidative stress influence testicular and sperm function. For this purpose we have determined the extent of lipid peroxidation, protein oxidation, activity of glutathione peroxidase and reductase, lactate and pyruvate levels, internal and external energetic charge and lactate dehydrogenase release, in isolated testicular cells of control and diabetic rats. We have also correlated these parameters with epididymal sperm count and sperm motility.

\section{Materials and methods}

\subsection{Materials}

All chemicals were obtained from Sigma, St. Louis, MO, USA.

\subsection{Animals and blood glucose determination}

\subsubsection{GK rats}

Spontaneously diabetic male GK rats, 3 months of age $(n=23)$, were obtained from our local breeding colony (Animal Research Center Laboratory, University Hospitals, Coimbra), established in 1995 with breeding couples from the colony at the Tohoku University School of Medicine (Sendai, Japan; courtesy of Dr. K. Susuki). Control animals were non-diabetic male Wistar rats of similar age $(n=23)$. Animals were kept under controlled light (12-h day/night cycle), temperature $\left(22-24{ }^{\circ} \mathrm{C}\right)$ and humidity $(50-60 \%)$ conditions and with free access to powdered rodent chow (diet AO4, Panlab, Spain) and water (pH 5.5), except during the fasting periods. In this study, the "Principles of Laboratory Animal Care" (NIH publication 83-25, 
revised 1985) were followed. Glycemia was determined from the tail vein using a commercial glucometer (Glucometer-Elite, Bayer).

\subsubsection{STZ rats: induction and characterization of STZ-Induced diabetes}

Male Wistar rats weighing about $200 \mathrm{~g}$ (2 months) were randomly divided into two groups of 10 animals each. In order to induce diabetes, one group was injected intraperitoneally with a single injection of streptozotocin (STZ, $50 \mathrm{mg} / \mathrm{kg}$ ), after a $16-\mathrm{h}$ fasting period. The volume used was always $0.5 \mathrm{ml} / 200 \mathrm{~g}$ body weight. Streptozotocin [2-deoxy-2-(3-methyl-3-nitrosurea) 1-D-glucopyranose] was prepared prior to use in $100 \mathrm{mM}$ citrate, $\mathrm{pH}$ 4.5. In the following $24 \mathrm{~h}$, animals were orally fed with glycosilated serum in order to avoid hypoglycemia resulting from massive destruction of $\beta$-cells, and release of intracellular insulin associated with STZ treatment [23]. Animals were kept for 1 week $(n=13), 1$ month $(n=21)$ and 3 months $(n=16)$ before the experiments. During this period, glycemia was determined from the tail vein. Values were taken in fasting conditions just before STZ administration, and in non-fasting conditions in the following weeks. If feeding blood glucose in the tail vein exceeded $250 \mathrm{mg} / \mathrm{dl}$, animals were used as diabetic. Control animals were non-diabetic male Wistar rats of similar age ( 3 months, $n=23$ and 5 months $n=14$ ), sham injected with the same volume of citrate solution.

\subsection{Rat sperm isolation}

After animal sacrifice by cervical dislocation, testes were removed with adherent epididymis and vas deferens. Epididymis and vans deferens were separated from testis and were put into $2 \mathrm{ml}$ prewarmed rat sperm isolation medium containing $17 \mathrm{mM} \mathrm{NaHCO}_{3}, 96.4 \mathrm{mM}$ $\mathrm{NaCl} ; 4.76 \mathrm{mM} \mathrm{KCl} ; 21.58 \mathrm{mM}$ Na-lactate; $5.56 \mathrm{mM}$ glucose; $1.71 \mathrm{mM} \mathrm{CaCl}_{2} ; 1.19 \mathrm{mM} \mathrm{KH}_{2} \mathrm{PO}_{4} ; 1.19 \mathrm{mM}$ $\mathrm{MgSO}_{4} ; 0.5 \mathrm{mM}$ Na-pyruvate; $4.0 \mathrm{mg} / \mathrm{ml} \mathrm{BSA} ; 50 \mu \mathrm{g} /$ $\mathrm{ml}$ streptomycin; $75 \mu \mathrm{g} / \mathrm{ml}$ penicillin; $20 \mathrm{mM}$ HEPES; $5 \mathrm{mg} / \mathrm{ml}$ phenol red; $\mathrm{pH}$ 7.3. Sperm was forced out of the vas deferens with fine forceps by putting pressure on the lower region of the cauda epididymis and "walking" the forceps down the vas deferens, not forcing out excess material, i.e., immature cells. As soon as sperm was released, $10 \mu \mathrm{l}$ of the concentrated sperm was draw up and transferred to a coverslip and spermatozoa motility and viability were evaluated. To immobilize spermatozoa, sperm was diluted twice in water and counted using a hemocytometer with Neubauer ruling $\left(400 \mathrm{sq} / \mathrm{mm}^{2}\right)$ using a bright field microscopy. We observed 100 spermatozoa for each sample in all assays.

\subsection{Isolation of testicular cells}

Testicular cells were isolated from adult rat testes using previously described methodology [30]. The testes were dissected into a Petri dish with EKRB (enriched Krebs-Ringer bicarbonate) medium containing $120.1 \mathrm{mM} \mathrm{NaCl}, 4.8 \mathrm{mM} \mathrm{KCl}, 25.2 \mathrm{mM} \mathrm{NaHCO}_{3}$, $1.2 \mathrm{mM} \mathrm{KH} \mathrm{KH}_{2} \mathrm{PO}_{4}\left(\mathrm{pH} 7.2\right.$ ), $1.2 \mathrm{mM} \mathrm{MgSO}_{4} .7 \mathrm{H}_{2} \mathrm{O}$, $1.3 \mathrm{mM} \mathrm{CaCl}_{2}$, supplemented with $11.1 \mathrm{mM}$ glucose, $1 \mathrm{mM}$ glutamine, $10 \mathrm{ml} / 1 \mathrm{MEM}$ essential amino acid solution (Sigma), $10 \mathrm{ml} / 1$ BME nonessential amino acid solution (Sigma), $100 \mathrm{mg} / \mathrm{ml}$ streptomycin, $100 \mathrm{U} / \mathrm{ml}$ penicillin (K salt) and $20 \mathrm{mM}$ HEPES. Dry collagenase was then added at a final concentration of $0.5 \mathrm{mg} / \mathrm{ml}$, and the testes were incubated for $15-45 \mathrm{~min}$ at $32{ }^{\circ} \mathrm{C}$ with gentle stirring. Once the seminiferous tubules were dispersed in the medium they were allowed to settle at the bottom of the dish, and the medium was aspirated and discarded. The tubules were then placed in fresh EKRB containing $1 \mathrm{mg} / \mathrm{ml}$ DNase I and $0.25 \mu \mathrm{g} / \mathrm{ml}$ trypsin and incubated for 15-45 min with stirring and gentle pipeting. After that, trypsin inhibitor was added to avoid destruction spermatogenic cells. Released spermatogenic cells were pelleted by centrifugation (10 min at $500 \mathrm{rpm}$ in a Sorval RT6000 refrigerated centrifuge) and washed twice in EKRB before being submitted to the next protocol. Round testicular cells were counted by using a hemocytometer with Neubauer ruling $\left(400 \mathrm{sq} / \mathrm{mm}^{2}\right)$ using a bright field microscopy.

\subsection{Determination of protein concentration}

The concentration of testicular proteins was estimated according the Sedmak method [31] using BSA (bovine serum albumin) as a standard.

\subsection{Analysis of adenine nucleotides}

Intracellular adenine nucleotides (ATP, ADP and AMP), from testicular cells were determined after cell extraction with $0.6 \mathrm{M}$ perchloric acid supplemented with $25 \mathrm{mM}$ EDTA-Na. Cells were centrifuged at 14,000 rpm in an Eppendorf 5417R centrifuge for $2 \mathrm{~min}$, at $0-4{ }^{\circ} \mathrm{C}$. The supernatants were neutralized with drop wise addition of $3 \mathrm{M} \mathrm{KOH}$ in $1.5 \mathrm{M}$ Tris and centrifuged at $14,000 \mathrm{rpm}$ for $2 \mathrm{~min}$, at $4{ }^{\circ} \mathrm{C}$. The resulting supernatants were assayed for internal ATP, ADP and AMP by separation in a reverse-phase high-performance liquid chromatography (HPLC) according to a previously described procedure [32]. The chromatography apparatus was a Beckman-System Gold, consisting of a 126 Binary Pump Model and 166 Variable UV detector controlled by 
a computer. The detection wavelength was $254 \mathrm{~nm}$, and the column was a Lichrosphere $100 \mathrm{RP}-18(5 \mu \mathrm{m})$ from Merck. An isocratic elution with $100 \mathrm{mM}$ phosphate buffer $\left(\mathrm{KH}_{2} \mathrm{PO}_{4} ; \mathrm{pH} 6.5\right)$ and $1.0 \%$ methanol was performed with a flow rate of $1 \mathrm{ml} / \mathrm{min}$. Peak identity was determined by following the retention time of standards. Adenylate energy charge (AEC) was determinated according the following formula: ATP $+0.5 \times \mathrm{ADP} /$ $(\mathrm{ATP}+\mathrm{ADP}+\mathrm{AMP})$.

\subsection{Lactate and pyruvate levels}

Lactate and pyruvate levels were determined using commercial ELISA-based assay kits for enzymatic quantification of lactate (\# LC2389, RANDOX, UK) and UV quantification of Pyruvate (\# 8825, BEN srl, Italy), respectively. Both kits were used in accordance with the manufacturers instructions.

\subsection{Oxidative stress parameters}

\subsubsection{Measurement of lipid peroxidation}

The extent of lipid peroxidation was determined by measuring the amount of thiobarbituric acid reactive species (TBARS) formed, according to a modified procedure [33]. To measure lipid peroxidation, $500 \mu \mathrm{l}$ of peroxidation reagent containing $18.8 \mathrm{ml}$ of cold $40 \%$ trichloroacetic acid (TCA), $0.375 \%$ of thiobarbituric acid (TBA), $0.25 \mathrm{M} \mathrm{HCl}$ and $6.8 \mathrm{mM}$ BHT (2.6-diterbutyl-4metilphenol) were added to $500 \mu \mathrm{l}$ of the test material. The mixture was heated at $100{ }^{\circ} \mathrm{C}$ during $10 \mathrm{~min}$, and was allowed to cool in ice before a $10 \mathrm{~min}$ centrifugation at $3000 \mathrm{rpm}$ in a Sorval RT6000 refrigerated centrifuge. The supernatant was collected and TBARS were spectrophotometrically quantified at $530 \mathrm{~nm}$, against a blank prepared under similar conditions, but in the absence of sample. The amount of TBARS formed was calculated using a molar extinction coefficient of $1.56 \times 10^{-5} \mathrm{M}^{-1} \mathrm{~cm}^{-1}$ for thiobarbituric acid and expressed as nmol TBARS/mg protein [34].

\subsubsection{Analysis of carbonyl groups}

The accumulation of oxidized proteins can be evaluated by the content of carbonyl groups that can be spectrophotometrically quantified via reaction with DNPH (2,4-dinitrophenilhidrazine) at $360 \mathrm{~nm}$, [35]. Cells were centrifuged at $14,000 \mathrm{rpm}$ for $6 \mathrm{~min}$, at 0 $4{ }^{\circ} \mathrm{C}$. The resulting pellet was solubilized in $1 \mathrm{ml} \mathrm{TCA}$ (trichloroacetic acid) and centrifuged $(10,000 \mathrm{rpm}$, $3 \mathrm{~min}$ ) in an Eppendorf 5417R centrifuge. The sediments were incubated with $500 \mu \mathrm{l}$ of $10 \mathrm{mM}$ DNPH (freshly prepared in $2 \mathrm{M} \mathrm{HCl}$, and kept in the dark) for $1 \mathrm{~h}$ at room temperature, with vortex agitation every $10 \mathrm{~min}$. Subsequently, $500 \mu \mathrm{l}$ of $20 \%$ TCA was added and samples were centrifuged at $11,000 \mathrm{rpm}$, for $3 \mathrm{~min}$. The supernatant was decanted and the pellet mixed with $1 \mathrm{ml}$ of a 1:1 ethanol: ethyl acetate solution. The pellet was then incubated with $900 \mu \mathrm{l}$ of $6 \mathrm{M}$ guanidine (prepared in PBS, pH 6.5), for $15 \mathrm{~min}$ at $37^{\circ} \mathrm{C}$ and again centrifuged (10,000 rpm, $3 \mathrm{~min})$. The supernatant was collected and protein oxidation was estimated spectrophotometrically at $360 \mathrm{~nm}$. For all samples a blank was prepared, which was incubated with $2 \mathrm{M} \mathrm{HCl}$ instead of DNPH. The carbonyl content was calculated using a molar extinction coefficient of $22 \mathrm{mM}^{-1} \mathrm{~cm}^{-1}$ for DNPH, and was expressed as nmol DNPH/mg protein.

\subsection{Enzymatic activities}

Before performing the enzymatic assays cells were lysed with $15 \mathrm{mM}$ Tris (pH 7.4) and submitted to three cycles of freezing/thawing.

\subsubsection{Measurement of lactate dehydrogenase release}

The viability of tersticular cells was assessed by monitoring the leakage of cytosolic lactate dehydrogenase $(\mathrm{LDH})$ to the extracellular medium. LDH activity was measured spectrophotometrically according to a previously described procedure [36], following the rate of conversion of reduced nicotinamide adenine nucleotide $(\mathrm{NADH})$ to oxidized form $\left(\mathrm{NAD}^{+}\right)$. The enzymatic assay was performed in the supernatant after cell centrifugation at 14,000 rpm during $6 \mathrm{~min}$ in an Eppendorf 5417R centrifuge. The reaction occurred at $30{ }^{\circ} \mathrm{C}$, with constant magnetic stirring, in a cuvette with $200 \mu \mathrm{l}$ of sample, $1500 \mu \mathrm{l}$ of $0.244 \mathrm{mM} \mathrm{NADH}$ and $150 \mu \mathrm{l}$ of $9.76 \mathrm{mM}$ pyruvate. Pyruvate and NADH solutions were prepared in Tris/ $\mathrm{NaCl}$ buffer (Tris $81.3 \mathrm{mM} / \mathrm{NaCl} 203.3 \mathrm{mM}$, pH 7.2). The control blank lacked pyruvate. Lactate dehydrogenase activity was calculated by monitories the absorbance change/min of $\mathrm{NADH}$ at $340 \mathrm{~nm}$, using a molar extinction coefficient of $0.631 \mathrm{nmol}^{-1} \mathrm{~mm}^{-1}$ for $\mathrm{NADH}$, and its activity was expressed as $\mathrm{nmol} \mathrm{NADH} / \mathrm{min} / \mathrm{mg}$ protein.

\subsubsection{Glutathione reductase}

Glutathione reductase (G-Red) activity was determined according to a modified method [37]. G-Red catalyses the reduction of oxidized glutathione (GSSG) to reduced glutathione (GSH) in the presence of NADPH. Briefly, the enzymatic assay was performed in the supernatant following cell lysis. Each sample $(100 \mu \mathrm{l})$ was incubated with $500 \mu \mathrm{l}$ of phosphate buffer 
(containing $0.2 \mathrm{M}$ of $\mathrm{K}_{2} \mathrm{HPO}_{4}$ and $2 \mathrm{mM}$ EDTA, $\mathrm{pH}$ 7.0) supplemented with $50 \mu \mathrm{l}$ of $2 \mathrm{mM}$ NADPH and $350 \mu \mathrm{H}_{2} \mathrm{O}$. The measurements were initiated with the addition of $50 \mu \mathrm{l} \mathrm{GSSG}(20 \mathrm{mM})$, for $400 \mathrm{~s}$, at $30^{\circ} \mathrm{C}$ with continuous magnetic stirring, against blanks prepared in absence of GSSG in a Jasco, V-560, UVvis spectrophotometer. Glutathione reductase activity was calculated by the absorbance change per minute of $\mathrm{NADPH}$ at $340 \mathrm{~nm}$, using a molar extinction coefficient of $6220 \mathrm{~cm}^{2} \mathrm{~mol}^{-1}$, and its activity was expressed as $\mathrm{nmol} \mathrm{NADPH} / \mathrm{min} / \mathrm{mg}$ protein.

\subsubsection{Glutathione peroxidase}

Glutathione peroxidase (G-Px) activity was determined spectrophotometrically [38]. In this method, GPx catalyses the oxidation of glutathione in the presence of tert-butyl hydroperoxide ( $t$-BHP). Oxidized glutathione is converted to the reduced form in the presence of glutathione reductase and NADPH, while NADPH is oxidized to $\mathrm{NADP}^{+}$. Briefly, the enzymatic assay was performed in the supernatant after cell lysis and centrifugation (as above). Each sample $(30 \mu \mathrm{l})$ was incubated for $5 \mathrm{~min}$, in the dark, with $100 \mu \mathrm{l}$ of phosphate buffer (containing $0.25 \mathrm{mM} \quad \mathrm{KH}_{2} \mathrm{PO}_{4}$, $0.25 \mathrm{mM} \mathrm{K}_{2} \mathrm{HPO}_{4}$ and $500 \mu \mathrm{M}$ EDTA, $\left.\mathrm{pH} 7\right), 100 \mu \mathrm{l}$ GSH (freshly made and protected from light), $100 \mu \mathrm{l}$ glutathione reductase ( 1 unit), and $460 \mu \mathrm{H}_{2} \mathrm{O}$. The quantification occurred after the addition of $100 \mu$ of NADPH $(2.5 \mathrm{mM})$ and $100 \mu \mathrm{l}$ of $t$-BHP, at $30{ }^{\circ} \mathrm{C}$ with continuous magnetic stirring. The measurements were made against blanks prepared in the absence of NADPH in a Jasco, V-560, UV-vis spectrophotometer. Glutathione peroxidase activity was calculated by the absorbance change per minute of NADPH at $340 \mathrm{~nm}$, using a molar extinction coefficient of, $6220 \mathrm{~cm}^{2} \mathrm{~mol}^{-1}$, and its activity was expressed as $\mathrm{nmol} \mathrm{NADPH} / \mathrm{min} / \mathrm{mg}$ protein.

\subsection{Statistical analysis}

All statistical analyses were done using the SPSS (Statistical Package for the Social Sciences Program), version 12.00, software for windows (SPSS Inc., Chicago, IL, USA). All variables were checked for normal distribution. Results are presented as mean \pm S.E.M. of the number of experiences indicated and statistical significance between diabetic and control rat groups was accessed using the MannWhitney $U$-test. Multiple comparisons were performed using one-way ANOVA, followed by the post hoc Tamhanes and $p \leq 0.05$ was considered significant. Bivariate correlation $(r)$ in different groups was evaluated by calculating the Pearson correlation coefficient with a two-tailed significance $(p)$.

\section{Results}

\subsection{Glycemia}

Blood glucose (non-fasting) levels, were significantly higher in diabetic rats when compared to respective controls $(p<0.001)$. However, GK rats presented mild hyperglycemias (110-330 mg/dl), while STZ-treated rats presented severe hyperglycemias ( $>293 \mathrm{mg} / \mathrm{dl}$ ), $p<0.001$ (Fig. 1).

\subsection{Epididymal sperm count and motility}

An effect of age was noted in control Wistar rats, with 5-month-old rats (controls for rats treated with STZ for 3 months) showing higher sperm counts and motility than 3-month-old rats (controls for all other experimental groups $)(p<0.01)$. Rats treated with STZ for 1 and 3 months showed significantly lower sperm count and motility than controls. Interestingly, sperm of rats treated with STZ for 1 week showed similar motility to that observed in Wistar controls (data not shown). Since sperm mature for several days to weeks in the epididymis [39], most spermatozoa analysed in this case are probably already epididymal at the time of

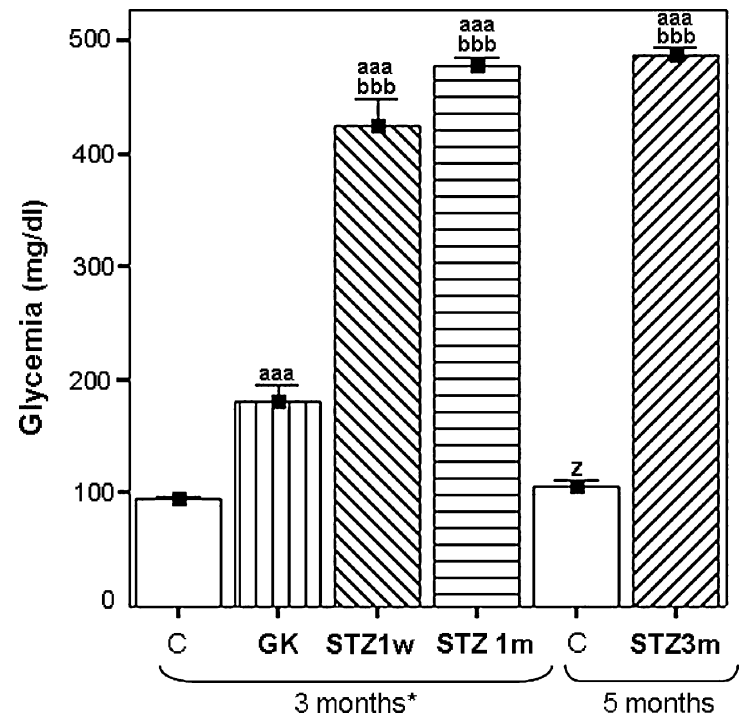

Fig. 1. Glycemia in diabetic and Wistar control rats. Glycemia was determinated as described in Section 2. Data is expressed as mean$\mathrm{s} \pm$ S.E.M. Statistical significance: (z) $p<0.05$ compared with 3month-old Wistar controls, (aaa) $p<0.001$ compared with Wistar control rats, (bbb) $p<0.001$ compared with GK rats. Three months * rats treated with STZ for 1 week are 2 months and 1 week old. 


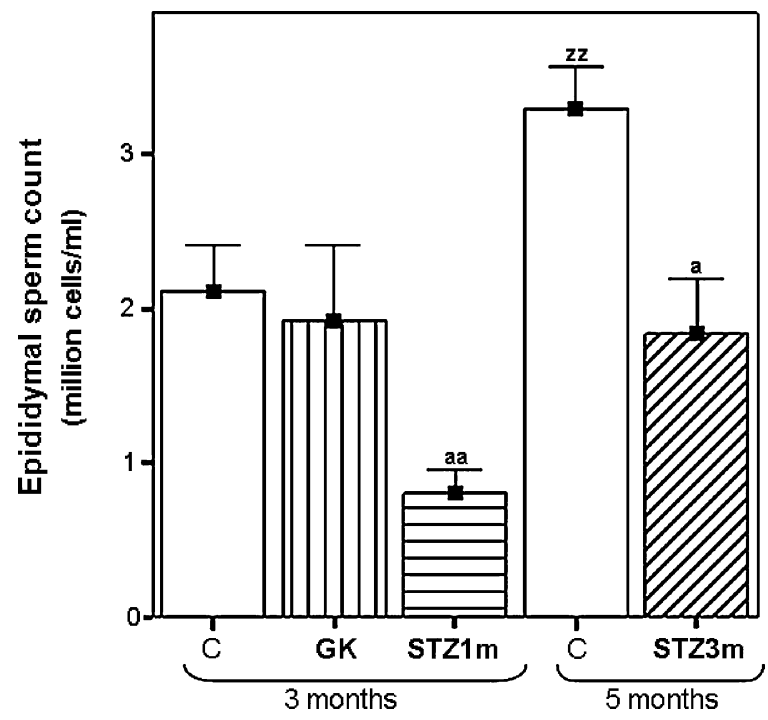

Fig. 2. Epididymal Sperm Count in Diabetic and Wistar control rats. Epididymal sperm count was determined as described in Section 2. Data is expressed as means \pm S.E.M. Statistical significance: ( $\mathrm{zz}$ and aa) $p<0.01$ compared with 3-month-old Wistar controls, (a) $p<0.05$, compared to 5-month-old Wistar controls.

streptozotocin injection. Thus we did not take into consideration rats treated with STZ for 1 week in analyses that involve sperm. On the other hand, sperm from GK rats showed a decrease in sperm count and motility compared with Wistar controls, however these differences were not statistically significant (Figs. 2 and 3 ). No differences were found in testicular round cell count (data not shown), suggesting that hiperglycemia affects the later stages of spermatogenesis.

\subsection{Analysis of adenine nucleotides and adenylate energy charge}

\subsubsection{Adenine nucleotides}

ATP levels were higher in 5-month-old Wistar control rats than in 3-month-old Wistar control rats

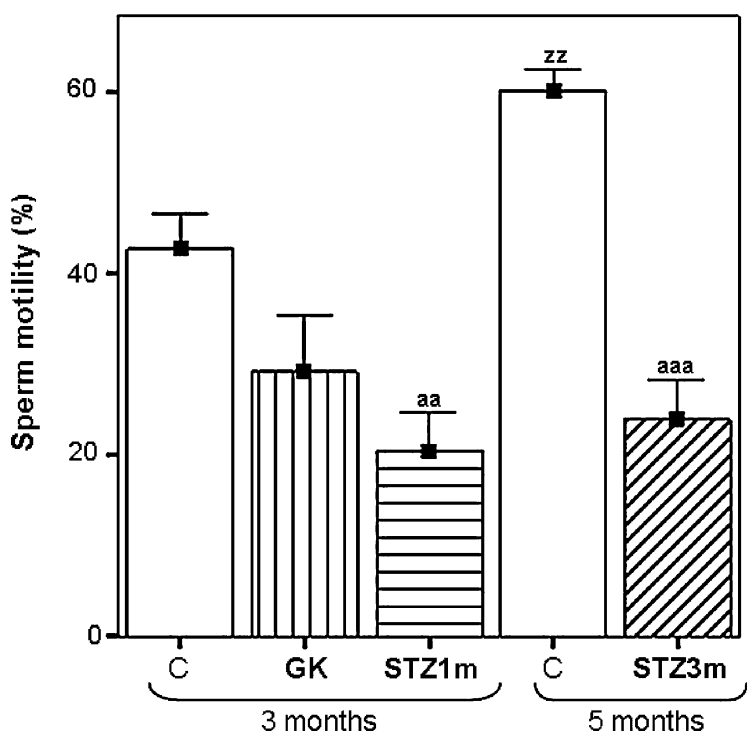

Fig. 3. Motility of epididymal sperm from diabetic and control rats. Sperm motility was determined as described in Section 2. Data is expressed as means \pm S.E.M. Statistical significance: (zz and aa) $p<0.01$ compared with 3-month-old Wistar controls and (aaa) $p<0.001$ compared with 5-month-old Wistar controls.

$(p<0.01)$. Rats treated with STZ for 3 months showed lower levels of ATP when compared with controls $(p<0.05)$, GK rats $(p<0.001)$ and rats treated with STZ for 1 month $(p<0.001)$. The same patterns were observed with ADP levels. AMP levels showed no agedependent changes in control rats, but showed a tendency to increase in rats treated with STZ for 1 month $(p<0.05)$. Rats treated with STZ for 3 months showed similar levels to the last group (Table 1).

\subsubsection{Adenylate energy charge (AEC)}

AEC in testicular cells from GK rats were very similar to Wistar controls. Conversely, AEC was lower in testicular cells of rats treated with STZ for 1 week $(p=0.058)$ and in rats treated with STZ for 3 months ( $p<0.05$, Fig. 4).

Table 1

ATP, ADP and AMP levels in rat testicular cells

\begin{tabular}{llcc}
\hline & ATP $(\mathrm{pmol} / \mathrm{mg}$ protein) & ADP $(\mathrm{pmol} / \mathrm{mg}$ protein) & AMP $(\mathrm{pmol} / \mathrm{mg}$ protein) \\
\hline Wistar controls (3 months) & $1386.9 \pm 288.4$ & $1976.6 \pm 374.1$ & $2276.6 \pm 449.1$ \\
GK rats (3 months) & $2013.4 \pm 286.4$ & $1597.05 \pm 162.1$ & $2681.1 \pm 680.3$ \\
STZ (1 week after treatment) & $1253.7 \pm 291.2$ & $2647.04 \pm 806.3$ & $4194.9 \pm 1279.4$ \\
STZ (1 month after treatment) & $2298.2 \pm 353.6$ & $2781.5 \pm 429.6$ & $4680.9 \pm 819.4 \mathrm{a}$ \\
Wistar controls (5 months) & $3521.3 \pm 550.6 \mathrm{zz}$ & $3882.8 \pm 581.9 \mathrm{z}$ & $2253.05 \pm 558.4$ \\
STZ (3 months after treatment) & $276.7 \pm 18.6 \mathrm{a}$,bbb,ddd & $1035.8 \pm 22.54 \mathrm{abd}$ & $4508.5 \pm 1648.6$ \\
\hline
\end{tabular}

Data is presented as means \pm S.E.M. for each condition studied. (zz) $p<0.01$ when compared with 3-month-old Wistar controls; (a) $p<0.05$ when compared with 5-month-old controls. (bbb and ddd) $p<0.001$ when compared with GK rats and with rats treated with STZ for 1 month, respectively. (z) $p<0.05$ when compared with 3-month-old controls (abd) $p<0.05$ when compared with 5-month-old Wistar controls, GK rats and rats treated with STZ for 1 month, respectively. (a) $p<0.05$ when compared with 3 -month-old controls. 


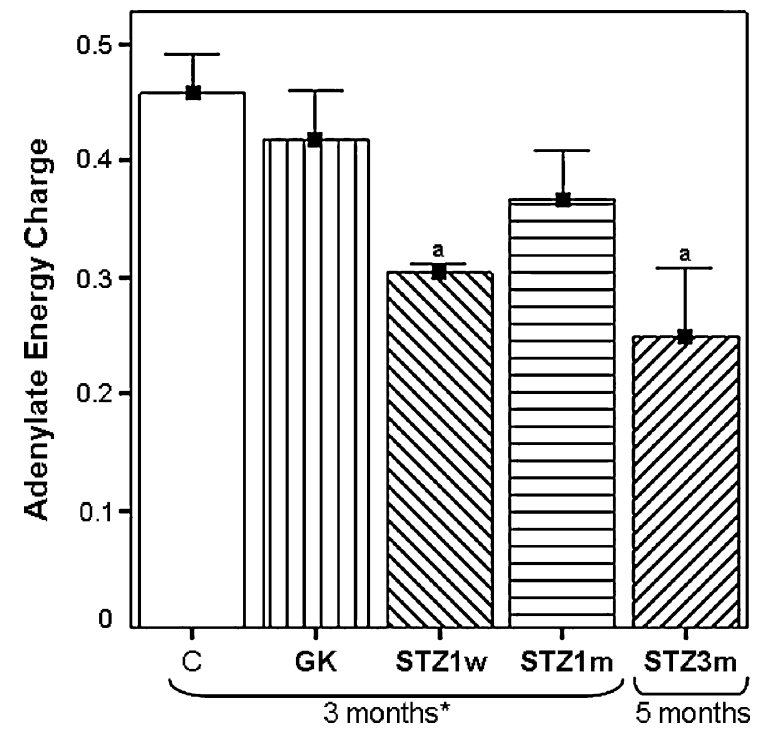

Fig. 4. Adenylate energy charge (AEC) in testicular cells of diabetic and control rats. AEC was determined as described in Section 2. Data is expressed as means \pm S.E.M. Statistical significance: (a) $p<0.05$ compared with Wistar control rats. This graph presents only one control bar because there were no differences between 3- and 5month-old Wistar control rats.

\subsection{Lactate and pyruvate levels}

Lactate levels were significantly lower in GK rats when compared with Wistar controls $(p<0.01)$. Also, rats treated with STZ for 3 months showed lower lactate levels when compared to their respective controls $(p<0.05)$, and higher levels when compared to GK and rats treated with STZ for 1 month $(p<0.01)$ (Fig. 5). No differences were found in pyruvate levels (data not shown).

\subsection{Oxidative stress parameters}

\subsubsection{Lipid peroxidation and protein oxidation}

Testicular cells of rats treated with STZ for 3 months showed a tendency towards higher susceptibility to lipid peroxidation, assessed by higher TBARS production, although this was not significant. Rats treated with STZ for 1 month showed lower TBARS levels when compared with controls and rats treated with STZ for 1 week $(p<0.05)$ (Fig. 6). No differences in carbonyl groups were found (data not shown).

\subsection{Enzymatic activities}

\subsubsection{Lactate dehydrogenase release}

We found no significant differences among different rat groups in the residual LDH activity

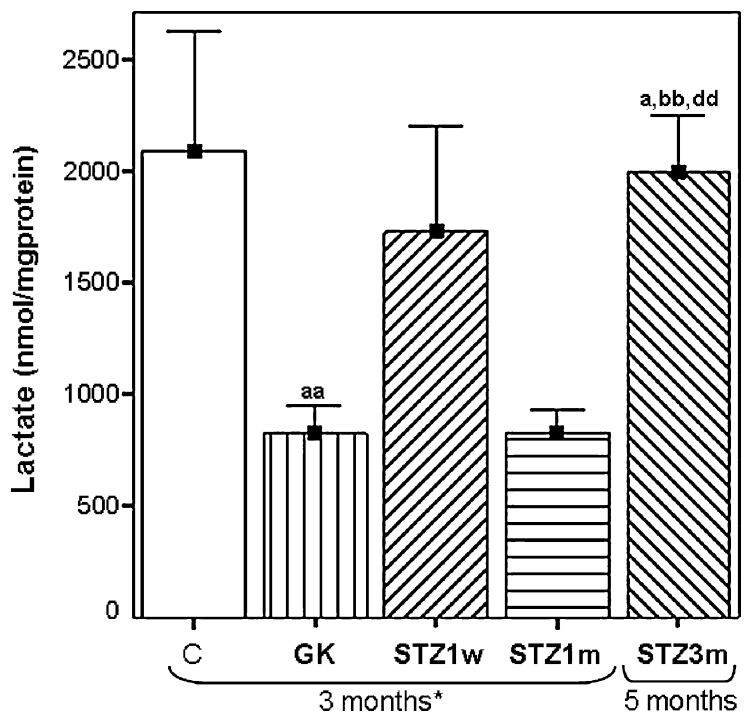

Fig. 5. Lactate levels in testicular cells of diabetic and control rats. Lactate levels were determined as described in Section 2. Data is expressed as means \pm S.E.M. Statistical significance: (a) $p<0.05$ and (aa) $p<0.01$ compared with Wistar control rats; (bb) $p<0.01$ compared with GK rats; (dd) $p<0.01$ compared with rats treated with STZ for 1 month. There were no differences between 3- and 5month-old Wistar control rats.

monitored in the supernatant of our cultures (data not shown), suggesting that testicular cell viability is not compromised during the experiment.

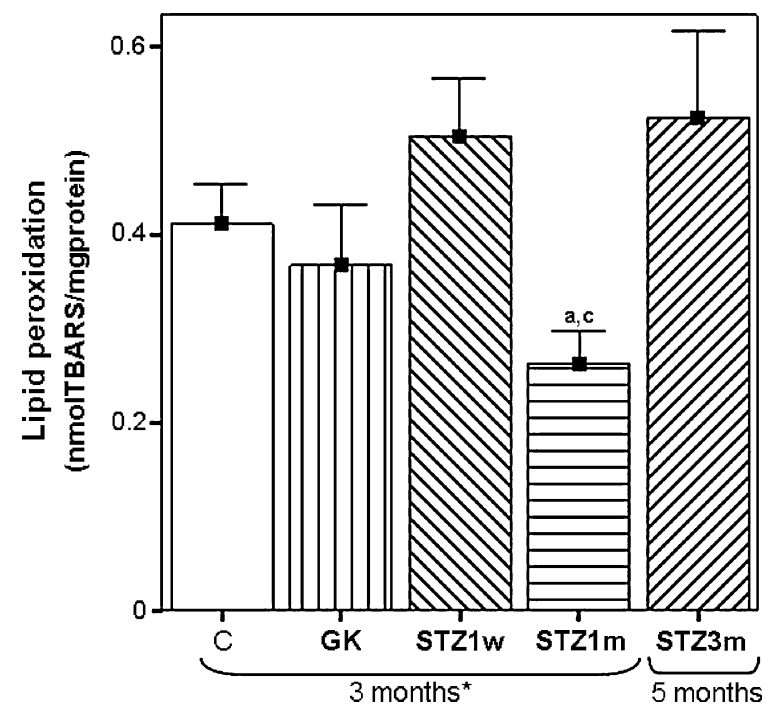

Fig. 6. Lipid peroxidation in diabetic and control rats. TBARS levels were determinated as described in Section 2. Data is expressed as means \pm S.E.M. Statistical significance: (a) $p<0.05$ compared with Wistar control rats; (c) $p<0.05$ compared with rats treated with STZ for 1 week. There were no differences between 3- and 5-month-old Wistar control rats. 


\subsubsection{Glutathione reductase activity}

Wistar control rats showed an increase in G-Red activity with age $(p<0.05)$. G-Red activity in the testicular cells of GK rats was higher when compared with Wistar controls $(p<0.05)$. In STZ-treated rats we observed that treatment for 3 months resulted in increased G-Red activity, compared with treatment for 1 week $(p<0.05)$ and 1 month $(p<0.01)$. Since we found no differences between STZ-treated rats and their controls these differences are likely due to age (Fig. 7).

\subsubsection{Glutathione peroxidase activity}

Our results show that G-Px activity decreases in testicular cells of GK rats $(p<0.05)$ and rats treated with STZ for 1 month $(p<0.05)$. However, G-Px activity was higher in rats treated with STZ for 3 months, compared to GK rats $(p<0.05)$ and STZ-treated rats for 1 month $(p<0.01)$. Therefore an enhancement of enzyme activity is evident in the later stage of the disease (Fig. 8).

\subsection{Correlations}

Both in controls and hyperglycemic rats, LDH activity was negatively correlated with ATP and positively correlated with TBARS, stressing that energy supply and oxidative stress are important factors for the maintenance of cellular viability, and suggesting the validity of our experimental approach. Also, G-Px activity correlated

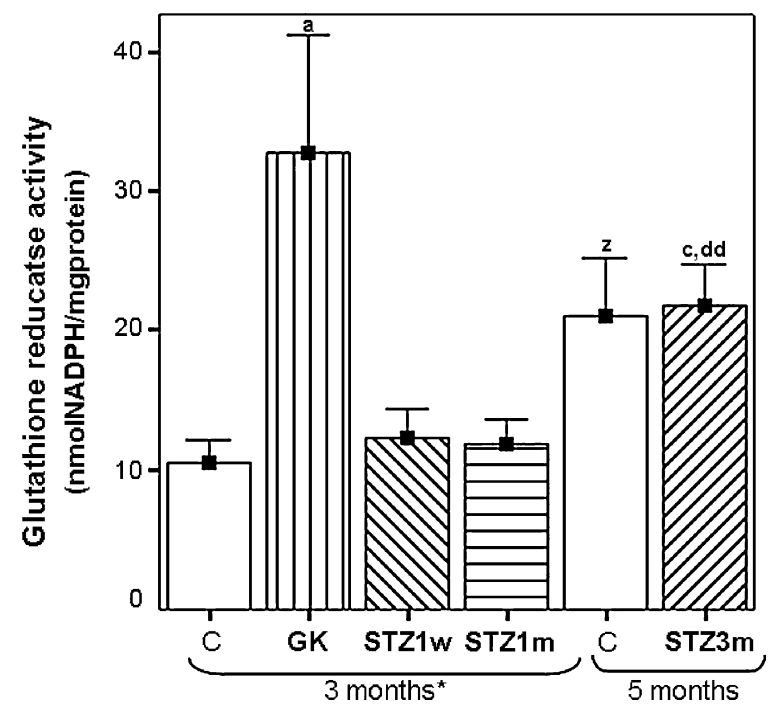

Fig. 7. Glutathione reductase activity in testicular cells of diabetic and control rats. Activity was determined as described in Section 2. Data is expressed as means \pm S.E.M. Statistical significance: ( $\mathrm{z}$ and a) $p<0.05$ compared with 3-month-old Wistar controls; (c) $p<0.05$ compared with rats treated with STZ for 1 week, (dd) $p<0.01$ compared with rats treated with STZ for 1 month.

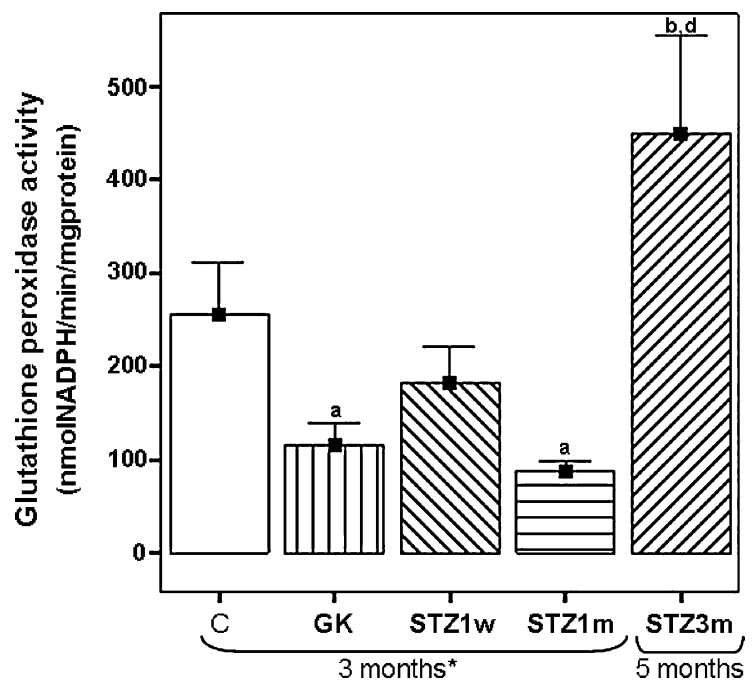

Fig. 8. Glutathione peroxidase activity in testicular cells of diabetic and control rats. Activity was determined as described in Section 2. Data is expressed as means \pm S.E.M. Statistical significance: (a) $p<0.05$ compared with Wistar controls; (b) $p<0.05$ compared with GK rats; (d) $p<0.05$ compared to rats treated with STZ for 1 month. There were no differences between 3- and 5-month-old Wistar control rats.

positively with LDH activity, TBARS and lactate levels, meaning that antioxidant defenses are triggered when the cell condition worsens, and that probably G-Px represents an active mechanism in protection against radicals originated by lipid peroxidation.

On the other hand, some important correlations were found that are likely due to the diabetic condition. A stronger negative correlation between ATP and TBARS was found in diabetic animals, mainly due to GK rats (data not shown), and the

Table 2

Correlations in parameters monitored for Wistar control rats (C) and hyperglycemic rats $(\mathrm{H})$

\begin{tabular}{|c|c|c|c|c|c|c|}
\hline & & LDH & TBARS & G-Px & G-Red & Lactate \\
\hline ATP & $\begin{array}{l}\mathrm{C} \\
\mathrm{H}\end{array}$ & $\begin{array}{l}-0.519^{*} \\
-0.522^{* *}\end{array}$ & $\begin{array}{l}-0.197 \\
-0.498^{\text {** }}\end{array}$ & $\begin{array}{c}0.121 \\
-0.457^{\text {** }}\end{array}$ & $\begin{array}{c}0.550^{*} \\
-0.43\end{array}$ & $\begin{array}{r}0.061 \\
-0.331\end{array}$ \\
\hline LDH & $\begin{array}{l}\mathrm{C} \\
\mathrm{H}\end{array}$ & & $\begin{array}{l}0.454^{* * *} \\
0.506^{* * *}\end{array}$ & $\begin{array}{l}0.608^{* * *} \\
0.524^{* *}\end{array}$ & $\begin{array}{r}-0.109 \\
0.168\end{array}$ & $\begin{array}{l}0.529^{* *} \\
-0.13\end{array}$ \\
\hline TBARS & $\begin{array}{l}\mathrm{C} \\
\mathrm{H}\end{array}$ & & & $\begin{array}{l}0.631^{\text {** }} \\
0.478^{\text {** }}\end{array}$ & $\begin{array}{r}0.002 \\
-0.009\end{array}$ & $\begin{array}{l}0.521^{\text {*** }} \\
0.358^{\text {** }}\end{array}$ \\
\hline G-Px & $\begin{array}{l}\mathrm{C} \\
\mathrm{H}\end{array}$ & & & & $\begin{array}{l}0.075 \\
0.282^{*}\end{array}$ & $\begin{array}{l}0.646^{* *} \\
0.304^{*}\end{array}$ \\
\hline G-Red & $\begin{array}{l}\mathrm{C} \\
\mathrm{H}\end{array}$ & & & & & $\begin{array}{l}0.270 \\
0.181\end{array}$ \\
\hline
\end{tabular}

Pearson correlation coefficients $(r)$ obtained in Wistar control rats $(\mathrm{C})$ and hyperglycaemic rats $(\mathrm{H})$ rats are presented. ${ }^{*} p \leq 0.05$ and ${ }^{* *} p \leq 0.01$. 
correlation between ATP with G-Px became negative, mainly due to rats treated with STZ (data not shown). Although not significant, the correlation between ATP and lactate also became negative in hyperglycemic rats. G-Px correlation with G-red also becomes evident, mainly due to rats treated with STZ (data not shown), suggesting the up-regulation of the glutathione pathway in the hyperglycemic testis. All bivariate correlations, calculated by the Pearson correlation coefficient, are presented in Table 2.

\section{Discussion}

Increasing evidence suggests that diabetes has an adverse effect on male reproductive function [2], and that oxidative stress may be involved [29]. According to Mahboob et al. [40], antioxidant enzyme-dependent defences may play an important role by scavenging free radicals produced under oxidative stress. The current study was conducted in order to clarify the relationship between oxidative stress originated by a diabetic condition, and parameters related to spermatogenesis and sperm function. For this purpose we used animal models for Type 1 (STZ-treated rats) and Type 2 (GK rats) diabetes, as well as control animals (Wistar rats). Overall, more severe effects were seen in rats treated with STZ for 3 months, while GK rats showed milder effects, possibly due to moderate hyperglycemia, or adaptations through selective breeding.

An age-dependent sperm concentration and motility increase was observed in control rats, but given that sexual maturity is reached by 8 weeks of age, 3-monthold rats may have not yet achieved the maximum potential for sperm production [41,42]. GK rats showed no differences in sperm parameters, while sperm concentration and motility decreased in rats treated with STZ, in accordance with some previous results [72,73], which have also described STZ-induced impairment in mating behaviour and sperm ejaculation. Furthermore, Soudamani et al. also found that STZinduced diabetes has detrimental effects on the maintenance and establishment of fully differentiated epididymal epithelium during sexual maturation [74].

Since we found no differences in testicular cell concentration between different groups, the decrease in sperm concentration is likely due to the influence of severe hyperglycemia in late stages of spermatogenesis, possibly through an increase in ROS. The consequences of such oxidative damage could include loss of motility due lipid peroxidation [43-45], induction of DNA damage in the sperm nucleus, and errors in spermiogenesis affecting fertilizing potential [45].
A major issue in hyperglycemic STZ-treated rats is a decrease in testicular ATP levels, leading to a compromised adenylate energy charge during spermatogenesis. Furthermore, the negative correlation observed between LDH and ATP levels in Wistar controls becomes stronger in hyperglycemic rats, mostly due to rats treated with STZ, stressing that cell energy supply is paramount for viability. Interestingly, GK rats and rats treated with STZ for 1 month showed a slight (non-significant) increase in ATP levels, when compared to other diabetic groups, suggesting that some kind of adaptation is underway in these rats, in order to increase ATP production. Metabolic adaptation may occur by an enhancement in oxidative phosphorylation in order to increase ATP production [28]. This adaptation was no longer seen in rats treated with STZ for 3 months, probably due to continuous severe hyperglycemia. Indeed, Ferreira et al. [28] demonstrated that liver mitochondria from GK rats presented improved respiratory activity and ATP synthase activity, as opposed to STZ-treated rats 9 weeks after diabetogenic treatment (corresponding to our rats treated with STZ for 3 months), which had decreased ATP synthase activity. If the respiratory enzymes of the electron transport chain are damaged by free radicals, the production of ATP is concurrently decreased [46]. Furthermore, a decline in ATP generation negatively affects glycolysis (since ATP is needed in the first stages), decreasing the use of glucose, fructose, and several amino acids, and leading to severe energetic impairment $[47,48]$. GK rats may also have the same metabolic adaptation due to genetic factors. Moreover, 3-month-old Wistar controls had inferior ATP levels when compared to 5-month-old controls, suggesting that similar changes occur with age [49-51], keeping in mind that age is also associated with increased oxidative stress [52-58].

A decrease in energy charge (decrease in ATP and increase in AMP) would switch off anabolic pathways, and switch on catabolic pathways, such as glycolysis and fatty acid oxidation [59]. We found that GK rats had similar AEC values to Wistar control rats, consistent with the proposed metabolic adaptations mentioned earlier. Among STZ-treated rats, despite a lower AEC in rats with 1 week and 3 months of STZ treatment, rats treated with STZ for 1 month presented a slight increase in AEC, in agreement with what was observed in terms of ATP levels. Furthermore, we suggest that rats treated with STZ for 1 week represent the acute phase of the disease, and have not yet adjusted their metabolism.

In Sertoli cells, glucose is metabolised via cytosolic glycolysis to lactate, which is then used primarily by the 
germ cells as a substrate for ATP production in mitochondrial oxidative phosphorylation [60]. The observed lowered lactate levels in GK rats and rats treated with STZ for 1 month may be explained by the variations observed in ATP, since if lactate levels drop if it is being used to produce ATP. Although not significant, it is interesting to note that the correlation between ATP and lactate became negative in hyperglycemic rats. Rats treated with STZ for 3 months showed higher lactate levels when compared to GK rats and rats treated with STZ for 1 month, but not when compared to control rats, although other observations relate the severity of diabetes with higher lactate levels [61]. In fact, hyperglycemia seems to enhance non-oxidative metabolism (glucose conversion to lactate), i.e. the Crabtree effect, by increasing glucose-6-phosphate levels (G6P). Increased glucose metabolism to lactate is associated with an increase in the NADH/NAD ${ }^{+}$ratio. Under this condition of markedly accelerated glycolysis, oxidation of glyceraldehyde 3-phosphate (GAP) to 1,3-biphosphoglycerate (1,3-DPG), coupled to the reduction of $\mathrm{NAD}^{+}$to $\mathrm{NADH}$, appears to become the rate-limiting step in glycolysis.. In the cytosol, NADH is oxidized to $\mathrm{NAD}^{+}$by lactate dehydrogenase (LDH), coupled by reduction of pyruvate to lactate. Thus, the increase in the ratio of NADH/NAD ${ }^{+}$will reflect an increased lactate/pyruvate ratio. The mechanism by which an increased rate of glycolysis increases free cytosolic NADH/NAD ${ }^{+}$ratio (redox imbalance) appears to result from an imbalance between the rate of oxidation of GAP to 1,3-DPG and the rate of reduction of pyruvate. This indicates that increased glycolysis, as a consequence of hyperglycemia, is closely related to an increase in the $\mathrm{NADH} / \mathrm{NAD}^{+}$ratio due to impaired oxidation of NADH to $\mathrm{NAD}^{+}[10]$.

If metabolic adjustments seem to be occurring what is the possible role of hyperglycemia in oxidative stress? Diabetic rats, with the exception of GK rats and rats treated with STZ for 1 month, had increased lipid peroxidation, in concordance with previous reports [10,40,62-65]. In rats treated with STZ for 1 month we observed a decrease in TBARS, when compared to controls and rats treated with STZ for 1 week, which may again represent an adaptive response to a chronic condition, in that the cells adapt to lower ROS production and/or increase inactivation of free radicals. In diabetic rats the negative correlation between TBARS and ATP levels became marked, demonstrating that the energetic state of the cell is important for the maintenance of proper levels of ROS. Additionally, a stronger positive correlation of TBARS levels with LDH activity was evident in diabetic rats, drawing a parallel between cellular viability and lipid peroxidation, and stressing that oxidative stress is related to cell loss.

In terms of possible enzymatic defences against the generation of ROS, conflicting reports, note both increased and decreased G-Px and G-Red activity in diabetic individuals [40,66-68]. In type 1 diabetes (STZ-treated rats), and discarding possible age-induced effects, we observed a decrease in G-Px activity in the early stages of the disease, followed by a significant increase. Moreover, for both enzyme activities correlations with ATP levels seen in Wistar controls are inverted in diabetic rats, mostly due to rats treated with STZ, and G-Px continues to be highly correlated with TBARS levels and LDH, implying that activity is higher when the cell condition is worse, and that G-Px represents an active mechanism in cell protection. Conversely, in type 2 diabetic rats (GK rats) these two enzymes had dissimilar patterns of variation, with a significant increase in G-Red activity, concomitant with a decrease in the activity of G-Px. Interestingly, this decrease mirrored what is seen in the early stages following STZ injection, thus stressing that there is some adaptation to hyperglycemia in STZ-treated rats. It is also possible that GK rats may need to regenerate GSH that might be oxidized by a G-Px independent pathway [69-71], thus justifying the higher activity of this enzyme.

Taken together these results allow us to conclude that hyperglycemia has adverse effects in energy levels, sperm concentration and sperm motility in model animals for type 1 diabetes, and that diabetic rats present some metabolic adaptations, augmenting the efficiency of ATP production and reducing ROS, in order to compensate the impairments promoted by high glucose levels typical of the disease. These adjustments are evident in GK rats and rats treated with STZ for 1 month and apparently disappear in the later stages of the disease.

\section{Acknowledgments}

This work was supported by Fundação para a Ciência e Tecnologia (FCT), Portugal (POCTI/ESP/ 38049/2001) and by Instituto de Investigação Interdisciplinar, University of Coimbra (III/BIO/50/2005). Sandra Amaral is a recipient of a fellowship from FCT (SFRH/BD/18734/2004). We thank Teresa Proença (University Hospitals, Coimbra) for help with pyruvate and lactate dosing, José Paulo Sousa and Sandra Gamboa for assistance with statistical analysis, Paula Mota, Ana Duarte, Pedro Oliveira and Paula Moreira 
for technical assistance, and J. Saints for language correction.

\section{References}

[1] Cameron DF, Rountree J, Schultz RE, Repetta D, Murray FT. Sustained hyperglycemia results in testicular dysfunction and reduced fertility potential in BBWOR diabetic rats. Am J Physiol 1990;259:881-9.

[2] Jiang GY. Practical diabetes Beijing: People's Health Publishing House; 1996. p. 295.

[3] Gavin III JR, Alberti KGMM, Davidson MB, De Fronzo RA, Drash A, Gabbe SG, et al. Report of the expert committee on the diagnosis and classification of diabetes mellitus. Diab Care 1997;20:1183-97.

[4] Malaisse WJ. Insulin release: the fuel concept. Diab Metab 1983;9:313-20.

[5] Giron MD, Salto R, Gonzalez Y, Giron JA, Nieto N, Periago JL, et al. Modulation of hepatic and intestinal glutathione $S$-transferases and other antioxidant enzymes by dietary lipids in streptozotocin diabetic rats. Chemosphere 1999;38:3003-13.

[6] Wiernsperger NF. Oxidative stress as a therapeutic target in diabetes: revisiting the controversy. Diab Metab 2003;29:57985.

[7] Ohkawa H, Ohishi N, Yagi K. Assay for lipid peroxides in animal tissues by thiobarbituric acid reaction. Anal Biochem 1979;95:351-8.

[8] Lee HC, Song YD, Li HR, Park JO, Suh HC, Lee E, et al. Mitochondrial gene transfer ribonucleic acid (tRNA) Leu (UUR) 3243 and (tRNA) Lys 8344 mutation and Diabetes mellitus in Korea. J Clin Endocrinol Metabol 1997;82:372-4.

[9] Jakus V, Rietbrock N. Advanced glycation end-products and the progress of diabetic vascular complications. Physiol Res 2004:53:131-42.

[10] Ahmed RG. The physiological and biochemical effects of diabetes on the balance between oxidative stress and antioxidant defense system. Med J Islamic World Acad Sci 2005;15:31-42.

[11] Taysi S, Polat F, Gul M, Sari RA, Bakan E. Lipid peroxidation, some extracellular antioxidants and antioxidant enzymes in serum of patients with rheumatoid arthritis. Rheumatol Int 2002;21:200-4.

[12] Michiels C, Raes M, Toussaint O, Remacle J. Importance of Seglutathione peroxidase, catalase, and $\mathrm{Cu} / \mathrm{Zn}$-SOD for cell survival against oxidative stress. Free Rad Biol Med 1994;17:235-48.

[13] Gul M, Kutay FZ, Temocin S, Hänninen O. Cellular and clinical implications of glutathione. Indian J Exp Biol 2000;38:625-34.

[14] Polat MF, Taysi S, Gul M, Cikman O, Yilmaz I, Bakan E, et al. Oxidant/antioxidant status in blood of patients with malignant breast tumour and benign breast disease. Cell Biochem Funct 2002;20:327-31.

[15] Yang J, Lam EW, Hammad HM, Oberley TD, Oberley LW. Antioxidant enzyme levels in oral squamous cell carcinoma and normal human oral epithelium. J Oral Pathol Med 2002;31:717.

[16] Pigeolet E, Corbisier P, Houbion A, Lambert D, Michiels C, Raes $\mathrm{M}$, et al. Glutathione peroxidase, superoxide dismutase, and catalase inactivation by peroxides, and oxygen derived free radicals. Mech Ageing Dev 1990;51:283-97.

[17] Sasvári M, Nyakas C. Time dependent changes in oxidative metabolism during chronic diabetes in rats. Acta Biologica Szegediensis 2003;47:153-8.
[18] Aitken RJ, Clarkson JS, Fishel S. Generation of reactive oxygen species, lipid peroxidation, and human sperm function. Biol Reprod 1989;41:183-97.

[19] Chen CS, Chao HT, Pan RL, Wei YH. Hydroxyl radical induced decline in motility and increase in lipid peroxidation and DNA modification in human sperm. Biochem Mol Biol Int 1997;43:291-303.

[20] Kao SH, Chao HT, Wei YH. Multiple detection of mitochondrial DNA associated with the decline of motility and fertility of human spermatozoa. Mol Hum Rep 1998;4:657-66.

[21] Kaemmerer H, Mitzkat HJ. Ion change chromatography of amino acids in ejaculate of diabetics. Andrologia 1985;17:485-7.

[22] McIntosh CHS, Pederson RA. Noninsulin-dependent animal models of diabetes mellitus. In: McNeill JH, editor. Experimental models of diabetes. Boca Raton, FL: CRC Press; 1999 p. 337-98.

[23] Rodrigues B, Poucheret P, Battell ML, McNeill JH. Streptozotocin-induced diabetes: induction, mechanisms(s), and dose dependency. In: McNeill JH, editor. Experimental models of diabetes. Boca Raton, FL: CRC Press; 1999. p. 3-17.

[24] Goto Y, Kakizaki M, Masaki N. Spontaneous diabetes produced by selective breeding of normal Wistar rats. Proc Jpn Acad 1975;51:80-5.

[25] Goto Y, Kakizaki M. The spontaneous-diabetes rat: a model of noninsulin dependent diabetes mellitus. Proc Jpn Acad 1981;57:381-4.

[26] Goto Y, Susuki K, Ono T, Sasaki M, Toyota T. Development of diabetes in non-obese NIDDM rat (GK) rat. Adv Exp Med Biol 1988;246:29-31.

[27] Serradas P, Gangnerau M-N, Giroix M-H, Saulnier C, Borg LAH, Portha B. Impaired pancreatic $\beta$-cell function in the fetal GK rat. J Clin Invest 1998;101:899-904.

[28] Ferreira FM, Palmeira CM, Seiça R, Moreno AJ, Santos MS. Diabetes and mitochondrial bioenergetics: alterations with age. J Biochem Mol Toxicol 2003;17:214-22.

[29] Rehman K, Beshay E, Carrier S. Diabetes and male sexual function. J Sex Reprod Med 2001;1:29-33.

[30] Bellve AR. Purification, culture, and fractionation of spermatogenic cells. Meth Enzymol 1993;225:84-113.

[31] Sedmak JJ, Grossberg FE. A rapid, sensitive and versatile assay for protein using coomassie brilliant blue G250. Anal Biochem 1977;79:544-52.

[32] Stocchi V, Cucchiarini L, Magnani M, Chiarantini L, Palma P, Crescentini G. Simultaneous extraction and reverse-phase highperformance liquid chromatographic determination of adenine and pyridine nucleotides in human red blood cells. Anal Biochem 1985;146:118-24.

[33] Ernester L, Nordenbrand K. Microssomal lipid peroxidation. Meth Enzymol 1967;10:574-8.

[34] Buege JA, Aust SD. Microssomal lipid peroxidation. Meth Enzymol 1978;52:302-10.

[35] Fagan JM, Sleczka BG, Sohar I. Quantitation of oxidative damage to tissue proteins. Int J Biochem Cell Biol 1999;31:751-7.

[36] Bergmeyer HU, Bernt E. UV-assay with pyruvate and NADH. In: Bergmeyer HU, editor. Methods enzymatic analysis. New York: Academic Press; 1974. p. 574-9.

[37] Goldberg DM, Richard SJ. Glutathione reductase. In: Bergmeyer HU, editor. Methods of enzymatic analysis, vol. 3. New York: Academic Press; 1983. p. 258-65.

[38] Paglia DE, Valentine WN. Studies on the quantitative and qualitative characterization of erythrocyte glutathione peroxidase. Lab Clin Med 1967;70:158-69. 
[39] Gatti J-L, Castella S, Dacheux F, Ecroyd H, Métayer S, Thimon $\mathrm{V}$, et al. Post-testicular sperm environment and fertility. Anim Reprod Sci 2004;82/83:321-39.

[40] Mahboob M, Rahman MF, Grover P. Serum lipid peroxidation and antioxidant enzyme levels in male and female diabetic patients. Singapore Med J 2005;46:322-4.

[41] Pass D, Freeth G. The rat. ANZCCART News 1993;6:1-4.

[42] Pritchett KR, Corning BF. Biology and medicine of rats. In: Reuter JD, Suckow MA, editors. Laboratory animal medicine and management. Ithaca, NY: International Veterinary Information Service; 2004.

[43] Oehninger S, Blackmore P, Mahony M, Hodgen G. Effects of hydrogen peroxide on human spermatozoa. J Assist Reprod Genet 1995;12:41-7.

[44] Sikka SC. Relative impact of oxidative stress on male reproductive function. Curr Med Chem 2001;8:851-62.

[45] Aitken RJ, Sawyer D. The human spermatozoon—not waving but drowning. Adv Exp Med Biol 2003;518:85-98.

[46] Hsu H-S, Wei Y-H, Li FA, Chen M-T, Chang LS. Defective mitochondrial oxidative phosphorylation in varicocele-bearing testicles. Urology 1995;46:545-9.

[47] Gerbitz KD, Gempel K, Brdiczka D. Mitochondria and diabetes-genetic, biochemical, and clinical implications of the cellular energy circuit. Diabetes 1996;45:113-26.

[48] Ferre T, Bosch F, Valera A. Evidence from transgenic mice that glucokinase is rate limiting for glucose utilization in the liver. FASEB J 1997;10:1213-8.

[49] Iossa S, Lionetti L, Mollica MP, Barletta A, Liverini G. Oxidative activity in mitochondria isolated from rat liver at different stages of development. Cell Biochem Funct 1998;16:261-8.

[50] Lionetti L, Iossa S, Leverini G, Brand MD. Changes in the hepatic mitochondrial respiratory system in the transition from weaning to adulthood in rats. Arch Biochem Biophys 1998;352:240-6.

[51] Kwong LK, Sohal RS. Age-related changes in activities of mitochondrial electron transport complexes in various tissues of the mouse. Arch Biochem Biophys 2000;373:16-22.

[52] Harman D. Free radical theory of aging. Mutat Res 1992; 275:257-66.

[53] Sohal RS, Weindruch R. Oxidative stress, caloric restriction, and aging. Science 1996;273:59-63.

[54] Martin GM, Austad SN, Johnson TE. Genetic analysis of ageing: role of oxidative damage and environmental stresses. Nat Genet 1996;13:25-34.

[55] Beckman KB, Ames BN. The free radical theory of aging matures. Physiol Rev 1998;78:547-81.

[56] Finkel T, Holbrook NJ. Oxidants, oxidative stress and the biology of ageing. Nature 2000;408:239-47.

[57] Wei Y-H, Lee HC. Oxidative stress, mitochondrial DNA mutation, and impairment of antioxidant enzymes in aging. Exp Biol Med 2002;227:671-82.

[58] Sheweita SA, Tilmisany AM, Al-Sawaf H. Mechanisms of male infertility: role of antioxidants. Curr Drug Metab 2005;6:495-501.
[59] Kemp BE, Stapleton D, Campbell DJ. AMP-activated protein kinase, super metabolic regulator. Biochem Soc Trans 2003; $31: 162-8$.

[60] Erkkika K, Aito H, Aalto K, Pentikäinen V, Dunkel L. Lactate inhibits germ cell apoptosis in the human testis. Mol Hum Reprod 2002;8:109-17.

[61] Strodter D, Lehmann E, Lehmann U, Tritschler HJ, Bretzel RG, Federlin K. The influence of thioctic acid on metabolism and function of the diabetic heart. Diab Res Clin Pract 1995;29:1926.

[62] Kinalski M, Śledziewski A, Telejko B, Zarzycki W, Kinalska I. Lipid peroxidation and scavenging enzyme activity in streptozotocin-induced diabetes. Acta Diabetol 2000;37:179-83.

[63] Seghrouchni I, Drai J, Bannier E, Riviére J, Calmard P, Garcia I, et al. Oxidative stress parameters in type I, type II and insulintreated type 2 diabetes mellitus; insulin treatment efficiency. Clin Chim Acta 2002;321:89-96.

[64] Memisogullari R, Taysi S, Bakan E, Capuglu I. Antioxidant status and lipid peroxidation in Type II diabetes mellitus. Cell Biochem Funct 2003;21:291-6.

[65] Davi G, Falco A, Patrono C. Lipid peroxidation in diabetes mellitus. Antioxid Redox Signal 2005;7:256-68.

[66] Matkovics B, Varga SI, Szabo L, Witas H. The effect of diabetes on the activities of the peroxide metabolism enzymes. Horm Metab Res 1982;14:77-9.

[67] Gupta BL, Azam M, Baquer NZ. Changes in erythrocyte glutathione peroxidase and glutathione reductase in alloxan diabetes. Biochem Int 1990;21:725-31.

[68] Peuchant E, Delmas-Beauvieux MC, Couchouron A, Dubourg L, Thomas MJ, Perromat A, et al. Short-term insulin therapy and normoglycemia. Effects on erythrocyte lipid peroxidation in NIDDM patients. Diab Care 1997;20:202-7.

[69] Wu G, Fang Y-Z, Yang S, Lupton JR, Turner N. Glutathione metabolism and its implications for health. J Nutr 2004;134: 489-92.

[70] Maher P. The effects of aging on glutathione metabolism. Aging Res Rev 2005;4:288-314.

[71] Knapen MF, Zusterzeel PL, Peters WH, Steegers EA. Glutathione and glutathione-related enzymes in reproduction. A review. Eur J Obstet Gynecol Reprod Biol 1999;82: 171-84.

[72] Sacarano WR, Messias AG, Oliva SU, Klinefelter GR, Kempinas WG. Sexual behaviour, sperm quantity and quality after shortterm streptozotocin-induced hyperglycaemia in rats. Int $\mathrm{J}$ Androl 2006; doi:10.1111/j.1365-2605.2006.00682.

[73] Hassan AA, Hassouana MM, Taketo T, Gagnon C, Elhiali MM. The effect of diabetes on sexual behaviour and reproductive tract function in male rats. J Urol 1993;149:148-54.

[74] Soudamani S, Malini T, Balasubramanian. Effects of streptozotocin-diabetes and insulin replacement on the epididymis of prepubertal rats: histological and histomorphometric studies. Endocr Res 2005;31:81-98. 